\title{
An Economic Study of Agricultural Investment in Egypt
}

\section{Eman Abd Elghafour Ahmed ${ }^{1}$ and Manal F. Mohamed ${ }^{2}$}

${ }^{2}$ Department of Agricultural Economic, Agriculture and Biological Division, National Research Centre, 33 El Buhouth St., 12622, Dokki, Giza, Egypt.

${ }^{2}$ Field Crop Department, Agriculture and Biological Division, National Research Centre, 33 El Buhouth St., 12622, Dokki, Giza, Egypt

Received: 20 Oct. 2019 / Accepted 10 Dec. 2019 / Publication date: 30 Dec. 2019

\begin{abstract}
Perhaps the relationship between domestic investment and economic growth lies in the importance of investment in increasing the rate of economic growth, through its ability to compensate for the lack of domestic savings, and thus stimulate further economic growth, as the effect of local investment in bringing about technological progress by investing in equipment and the new capital machinery accompanying local investments, leading to an increase in the overall productivity of the factors of production. This research aims to study the impact of agricultural investment on the performance of Egyptian economic growth during the period (2005-2018). In achieving its objectives, the research relied on methods of descriptive and quantitative statistical analysis, Where some statistical analytical methods were used, such as time series analysis, simple and multiple regression, One Way ANOVA test to determine the extent of variation in the investment value in different commodity sectors, the Duncan test used to test the multiple range to determine the extent of variation in the value of the rate of return on Investment in different commodity sectors, and the partial adjustment model of Nirulov was used to estimate the factors determining the targeted agricultural investment in the various mathematical models after selecting the most suitable ones. The Klein model was also used to measure the efficiency of agricultural investment through the method of minimizing the small squares in two stages.
\end{abstract}

Keywords: Agricultural investment, economic growth, investment rate, return on investment, capital intensification factor.

\section{Introduction}

The process of economic development depends on bringing about structural changes, through the transformation from a productive structure that depends on agricultural primary products to a productive structure characterized by a high ratio of industrial production to the gross national product, and the success of the economic development process depends on its ability to increase the volume of total investments, whether local or foreign, and distributing them among the various programs and projects and achieving the highest possible efficiency from the use of those investments, and introducing modern production methods that lead to an increase in total production, and then increasing total exports and reducing the gap in the overall trade balance.

Investment is considered the most important reason for the components of achieving economic development in Egypt for the main role in bringing about change in the economic structure, increasing the rate of economic performance and establishing projects that lead to an increase in national income and achieve economic well-being for members of society, as the total value of national investments in various economic sectors about 345.4 billion pounds, while the value of agricultural investment amounted to about 21.2 billion pounds, with a contribution rate of about $5.5 \%$ of the total value of national investments during the average period (2011-2018).

Despite the importance of the agricultural sector in the Egyptian economic structure, as it represents one of the main pillars on which the Egyptian economic structure is based, as the value of the agricultural GDP represents about $11.4 \%$ of the value of the gross domestic product, which amounts to about 2979 billion pounds, and despite the importance of total investment as one of the components

Corresponding Author: Eman Abd Elghafour Ahmed, Department of Agricultural Economic, Agriculture and Biological Division, National Research Centre, 33 El Buhouth St., 12622, Dokki, Giza, Egypt. E-mail: eman_6611@yahoo.com 
of output The local national, and despite the high return on investment in agricultural projects, reaching about 20.8 during the average period (2011-2018).

However, the agricultural sector still suffers from a small percentage of the agricultural investment contribution to the total value of national investments, which led to a decrease in the number of agricultural workers from about 6.88 million workers in 2008 to about 5.69 million workers in 2018 and a decrease in the relative importance of agricultural labor out of the total labor force. This negatively affected the performance of the agricultural sector, and thus the rates of agricultural development in Egypt decreased, which necessitates directing economic policies towards increasing agricultural sector investments.

To achieve the desired development goals and achieve the highest rate of self-sufficiency in strategic commodities produced by the agricultural sector, and to encourage agricultural investment and accelerate agricultural and economic development.

\section{Research objectives:}

This research aims to study the most important determinants of agricultural investment in Egypt during the period (2005-2018) through:

1. To Study the evolution of the relative importance of agricultural investment from the total domestic investment.

2. Measuring the investment efficiency of the different sectors, according to some criteria for measuring investment efficiency (investment rate, return on investment, and capital intensification coefficient (employment factor) during the period (2005-2018).

3. Measuring estimation of the most important determinants of agricultural investment in Egypt during the period (2005-2018), using the Nerlove's partial adjustment model to estimate the extent of deviation of agricultural investments from the targeted investments.

4. The standard estimation of the Klein model to measure the efficiency of agricultural investment in Egypt.

5. The standard estimation of the Harrod and Domer model to measure the rate of growth of real agricultural income.

In achieving its objectives, this research relied on the methods of descriptive and quantitative statistical analysis, where some statistical analytical methods were used, such as time series analysis, simple and multiple regression, and the One Way ANOVA test to determine the extent of a variation in the investment value in different commodity sectors, and the use of some criteria Measuring the efficiency of agricultural investment, and the Duncan test was used to test the multi-term to determine the extent of variation in the value of the rate of return on investment for different commodity sectors. The (Klein model) was also estimated using the simultaneous equations method in a two-stage least square method, in addition to using the Nerlove's partial Adjustment Model to estimate the extent of deviation of agricultural investments from the targeted investments. The study relied on secondary data published in many official bodies such as the Ministry of Agriculture and Land Reclamation, the Central Agency for Public Mobilization and Statistics, and the Ministry of Planning, and some research, letters, studies and scientific books related to the research topic were also used.

\section{Research findings and Discussion}

First: The chronological development of the study variables during the period (2005-2018):

By studying the development of total domestic investment, it was found that it increased from about 115.7 billion pounds in 2005 to about 513.7 billion pounds in 2018, an increase of about $344 \%$ from 2005, and by studying the equation of the general time trend of total domestic investment, it was found that it took an increasing general trend of about 25.06 billion pounds. It represents about $9.0 \%$ of the average of about 279.3 billion pounds during the study period.

The study of the development of agricultural investment also showed that it increased from about 8.04 billion pounds in 2005 to about 49.21 billion pounds in 2018 , an increase of about $512 \%$ from 2005 , and by studying the equation of the general time trend of total agricultural investment, it was found that it took an increasing general trend of about 1.55 billion. EGP represents about $10.1 \%$ of the average of about 15.31 billion pounds during the study period, as it was found that the relative 
importance of agricultural investment to the total investment amounted to about $4.46 \%$ during the average study period Table (1).

Table 1: Equations for the general temporal trend of the evolution of the study variables during the period (2005-2018)

\begin{tabular}{llcccc}
\hline Variable & Sample & Growth rate & Average & $\mathbf{R}^{2}$ & F \\
\hline $\begin{array}{l}\text { Total investment } \\
\text { (Billion pounds) }\end{array}$ & $\begin{array}{l}\hat{\mathrm{Y}}_{2}=91.42+25.06 \mathrm{~T} \\
(8.30)^{* *}\end{array}$ & 9.0 & 279.3 & 0.852 & $68.9^{* *}$ \\
$\begin{array}{l}\text { Agricultural } \\
\text { investment } \\
\text { (Billion pounds) }\end{array}$ & $\begin{array}{l}\hat{\mathrm{Y}}_{2}=0.828+1.55 \mathrm{~T} \\
(4.93)^{* *}\end{array}$ & 10.1 & 15.31 & 0.669 & $24.3^{* *}$ \\
\hline
\end{tabular}

**Morale when, $0.01 *$ Morale when 0.05

Source: It was collected and calculated from Table (1) by research.

Table 2: The evolution of the total domestic investment and agricultural investment in Egypt during the period (2005-2018) (value: one billion pounds)

\begin{tabular}{cccc}
\hline Year & $\begin{array}{c}\text { Total agricultural } \\
\text { investment }\end{array}$ & $\begin{array}{c}\text { Total domestic } \\
\text { investment }\end{array}$ & \% \\
\hline $\mathbf{2 0 0 5}$ & 8.04 & 115.7 & 6.9 \\
$\mathbf{2 0 0 6}$ & 7.79 & 155.3 & 5.0 \\
$\mathbf{2 0 0 7}$ & 8.07 & 199.5 & 4.0 \\
$\mathbf{2 0 0 8}$ & 6.86 & 215.7 & 3.2 \\
$\mathbf{2 0 0 9}$ & 6.74 & 231.8 & 2.9 \\
$\mathbf{2 0 1 0}$ & 6.83 & 229.1 & 3.0 \\
$\mathbf{2 0 1 1}$ & 5.37 & 246.1 & 2.2 \\
$\mathbf{2 0 1 2}$ & 8.38 & 241.6 & 3.5 \\
$\mathbf{2 0 1 3}$ & 11.63 & 265.1 & 4.4 \\
$\mathbf{2 0 1 4}$ & 13.41 & 333.7 & 4.0 \\
$\mathbf{2 0 1 5}$ & 16.28 & 392.0 & 4.2 \\
$\mathbf{2 0 1 6}$ & 17.34 & 300.8 & 5.8 \\
$\mathbf{2 0 1 7}$ & 48.39 & 470.5 & 10.3 \\
$\mathbf{2 0 1 8}$ & 49.21 & 513.7 & 9.6 \\
Average & 15.31 & 279.3 & 4.46 \\
\hline
\end{tabular}

Source: compiled and calculated from:

1- Central Agency for Public Mobilization and Statistics, the annual statistical book, miscellaneous issues.

2- Website of the Central Agency for Public Mobilization and Statistics: w.capmas.gov.eg

Second: Measuring the efficiency of investment in the various economic sectors, using some efficiency measurement criteria:

Agricultural investment is one of the most important factors that lead to the success of the agricultural development process, as it is considered the most important resource for increasing production and agricultural income and creating new job opportunities. The success of the agricultural development process depends on its ability to increase the volume of available agricultural investments and distribute them to various productive programs to achieve the highest possible production efficiency. And to find out the efficiency of investment in the agricultural sector through the use of some criteria for measuring the efficiency of agricultural investment, including:

\section{Rate of investment:}

The investment rate shows the size of the investment necessary to produce one unit of agricultural output, and the decrease in the value of the investment rate from the correct one reflects the existence of efficiency in agricultural investment and vice versa by increasing the value of this rate over the correct one, and it is calculated through the following equation:

$$
\text { The rate of investment }=\frac{\text { Investment }}{\text { Gross domestic product }}
$$

The development of the agricultural investment rate revealed that it ranged between a maximum of about 1.66 for the electricity sector, and a minimum of about 0.03 for the construction and agricultural 
sectors, which is less than the correct one, which indicates the efficiency of investment in the construction and agricultural sectors, in order to reduce the investment value required to produce a unit One of the outcomes during the study period - Table (3).

Table 3: The evolution of the investment rate results for the different economic sectors in Egypt during the period (2005-2018)

\begin{tabular}{cccccc}
\hline Year & Construction & Electricity & Petroleum & Industry & Agriculture \\
\hline $\mathbf{2 0 0 5}$ & 0.21 & 1.02 & 0.41 & 0.16 & 0.08 \\
$\mathbf{2 0 0 6}$ & 0.10 & 0.87 & 0.30 & 0.43 & 0.08 \\
$\mathbf{2 0 0 7}$ & 0.11 & 1.09 & 0.35 & 0.37 & 0.07 \\
$\mathbf{2 0 0 8}$ & 0.10 & 1.35 & 0.29 & 0.21 & 0.05 \\
$\mathbf{2 0 0 9}$ & 0.09 & 1.22 & 0.41 & 0.16 & 0.04 \\
$\mathbf{2 0 1 0}$ & 0.11 & 1.13 & 0.27 & 0.12 & 0.04 \\
$\mathbf{2 0 1 1}$ & 0.03 & 1.10 & 0.32 & 0.10 & 0.03 \\
$\mathbf{2 0 1 2}$ & 0.05 & 0.82 & 0.24 & 0.09 & 0.04 \\
$\mathbf{2 0 1 3}$ & 0.03 & 0.64 & 0.17 & 0.15 & 0.05 \\
$\mathbf{2 0 1 4}$ & 0.04 & 0.44 & 0.15 & 0.12 & 0.05 \\
$\mathbf{2 0 1 5}$ & 0.11 & 0.47 & 0.17 & 0.07 & 0.05 \\
$\mathbf{2 0 1 6}$ & 0.06 & 1.53 & 0.14 & 0.14 & 0.04 \\
$\mathbf{2 0 1 7}$ & 0.22 & 1.66 & 0.04 & 0.18 & 0.10 \\
$\mathbf{2 0 1 8}$ & 0.19 & 1.58 & 0.04 & 0.19 & 0.08 \\
Average & 0.10 & 1.07 & 0.24 & 0.18 & 0.06 \\
\hline
\end{tabular}

Source: It was collected and calculated from Table (2) by research.

\section{Return on investment (productivity of investment)}

The return on investment shows the inverse of the rate of investment, which is the value of the output generated from one unit of agricultural investment, and the rise in the value of the return on investment over the correct one reflects the existence of efficiency in agricultural investment, and is calculated through the following equation:

$$
\text { Return on investment }=\frac{\text { Gross domestic product }}{\text { Investment }}
$$

It is evident from the development of the return on agricultural investment that it ranged between a minimum of about 0.6 for the electricity sector, and a maximum of about 35.3, 34.7 for the construction and agricultural sectors, which is greater than the correct one, which indicates the efficiency of investment in the agricultural sector, due to the high value of the productivity of the investment unit Agricultural equipment during the study period - Table (4).

Table 4: Evolution of the results of return on investment for the various economic sectors in Egypt during the period (2005-2018)

\begin{tabular}{cccccc}
\hline Year & Construction & Electricity & petroleum & Industry & Agriculture \\
\hline $\mathbf{2 0 0 5}$ & 4.9 & 1.0 & 2.4 & 6.2 & 12.4 \\
$\mathbf{2 0 0 6}$ & 9.7 & 1.2 & 3.3 & 2.4 & 13.0 \\
$\mathbf{2 0 0 7}$ & 9.1 & 0.9 & 2.8 & 2.7 & 14.0 \\
$\mathbf{2 0 0 8}$ & 9.6 & 0.7 & 3.5 & 4.7 & 19.6 \\
$\mathbf{2 0 0 9}$ & 10.6 & 0.8 & 2.4 & 6.4 & 23.8 \\
$\mathbf{2 0 1 0}$ & 9.1 & 0.9 & 3.7 & 8.2 & 26.6 \\
$\mathbf{2 0 1 1}$ & 35.3 & 0.9 & 3.1 & 9.6 & 34.7 \\
$\mathbf{2 0 1 2}$ & 20.6 & 1.2 & 4.1 & 11.2 & 25.0 \\
$\mathbf{2 0 1 3}$ & 28.9 & 1.6 & 5.9 & 8.8 & 20.8 \\
$\mathbf{2 0 1 4}$ & 24.3 & 2.3 & 6.0 & 15.0 & 20.8 \\
$\mathbf{2 0 1 5}$ & 8.8 & 2.1 & 7.0 & 7.0 & 19.6 \\
$\mathbf{2 0 1 6}$ & 16.8 & 0.7 & 28.0 & 5.5 & 23.0 \\
$\mathbf{2 0 1 7}$ & 4.5 & 0.6 & 25.2 & 5.3 & 10.3 \\
$\mathbf{2 0 1 8}$ & 5.3 & 0.6 & 7.4 & 7.1 & 1.9 \\
Average & 14.1 & 1.1 & 19.7 & \\
\hline
\end{tabular}

Source: It was collected and calculated from Table (2) by research. 


\section{Capital Intensification Coefficient (Employment)}

The increase in national income leads to an increase in agricultural spending in the short term according to the multiplier theory, which is known as the income effect. It also affects the increase in the productive capacities of agricultural projects, which is known as the capacity effect, and the capital intensity factor (employment) shows the ratio between agricultural investment and the number of workers, and the more Its value for the correct one whenever this indicates that the agricultural sector is a capital intensive activity and vice versa, and is calculated through the following equation:

$$
\text { Capital Intensification Coefficient (Employment) }=\frac{\text { Investment }}{\text { Number of Workers }}
$$

The results of the development of the agricultural capital intensification factor also showed that it ranged between a maximum of about 569 in the electricity sector, and a minimum that averaged about 2.4 in the agricultural sector, which is greater than the correct one, indicating that the agricultural sector is an intensive activity for capital use during the study period. Table (5).

Table 5: Evolution of the results of the employment factor * for the different economic sectors in Egypt during the period (2005-2018)

\begin{tabular}{cccccc}
\hline Year & Construction & Electricity & Petroleum & Industry & Agriculture \\
\hline $\mathbf{2 0 0 5}$ & 2.9 & 55.1 & 386.1 & 6.5 & 1.3 \\
$\mathbf{2 0 0 6}$ & 1.3 & 51.9 & 400.2 & 15.1 & 1.2 \\
$\mathbf{2 0 0 7}$ & 1.4 & 72.0 & 404.3 & 11.2 & 1.3 \\
$\mathbf{2 0 0 8}$ & 1.6 & 102.5 & 362.0 & 8.9 & 1.0 \\
$\mathbf{2 0 0 9}$ & 1.5 & 101.5 & 506.6 & 8.2 & 1.0 \\
$\mathbf{2 0 1 0}$ & 2.1 & 63.4 & 349.4 & 9.8 & 1.0 \\
$\mathbf{2 0 1 1}$ & 0.6 & 70.7 & 462.0 & 8.1 & 0.8 \\
$\mathbf{2 0 1 2}$ & 1.2 & 61.8 & 484.7 & 15.0 & 1.3 \\
$\mathbf{2 0 1 3}$ & 1.0 & 60.3 & 366.4 & 15.5 & 1.7 \\
$\mathbf{2 0 1 4}$ & 1.4 & 66.4 & 251.2 & 3.5 & 2.0 \\
$\mathbf{2 0 1 5}$ & 3.9 & 89.9 & 232.8 & 15.5 & 2.5 \\
$\mathbf{2 0 1 6}$ & 2.9 & 349.9 & 71.9 & 25.4 & 2.7 \\
$\mathbf{2 0 1 7}$ & 12.8 & 473.3 & 52.3 & 33.9 & \\
$\mathbf{2 0 1 8}$ & 14.3 & 569.0 & 331.2 & 14.0 & \\
Average & 3.5 & 156.3 & & & \\
\hline
\end{tabular}

*Employment factor: one billion pounds / million workers

Source: It was collected and calculated from Table (2) by research.

Third: To test the variation in investment efficiency rates for the different economic sectors in Egypt:

A one-way analysis of variance was conducted to determine the extent of variation in investment efficiency rates for the different economic sectors in Egypt during the period (2005-2018), as it was found from the results of Tables (6 to 9) that there were statistically confirmed significant differences at the probability level 0.01 in The value of the investment rate, the return on investment, the employment factor, the investment value among the different economic sectors during the study period.

Table 6: Results of the one-way variation in the investment rate between the most important different economic sectors during the period (2005-2018)

\begin{tabular}{lccccc}
\hline Source of variance & Sum of Squares & df & Mean Square & F & Sig. \\
\hline Between Groups & 9.8 & 4 & 2.45 & 67.4 & 0.000 \\
Within Groups & 2.4 & 65 & 0.04 & & \\
Total & 12.1 & 69 & & & \\
Source: It was collected and calculated from Table (3) by research.
\end{tabular}


Table 7: Results of the variation in one-way return on investment between the most important different economic sectors during the period (2005-2018)

\begin{tabular}{lccccc}
\hline Source of variance & $\begin{array}{c}\text { Sum of } \\
\text { Squares }\end{array}$ & df & Mean Square & F & Sig. \\
\hline Between Groups & 2865 & 4 & 716.30 & 16.3 & 0.000 \\
Within Groups & 2856 & 65 & 43.94 & & \\
Total & 5721 & 69 & & & \\
\hline
\end{tabular}

Source: It was collected and calculated from Table (4) by research.

Table 8: The results of the one-way variation of the employment factor among the most important different economic sectors during the period (2005-2018)

\begin{tabular}{lccccc}
\hline Source of variance & Sum of Squares & df & Mean Square & F & Sig. \\
\hline Between Groups & 1159599 & 4 & 289900 & 29.5 & 0.000 \\
Within Groups & 638893 & 65 & 9829.1 & & \\
Total & & & 69 & 1798492 & Total \\
\hline
\end{tabular}

Source: It was collected and calculated from Table (4) by research.

Table 9: Results of the discrepancy in one direction of the investment value in different economic sectors in billions of pounds during the period (2005-2018)

\begin{tabular}{lccccc}
\hline Source of variance & Sum of Squares & df & Mean Square & F & Sig. \\
\hline Between Groups & 12645 & 4 & 3161.18 & 5.9 & 0.000 \\
Within Groups & 34744 & 65 & 534.52 & & \\
Total & 47389 & 69 & & & \\
\hline
\end{tabular}

Duncan's New Multiple Range Test was used, as it was found from the results of Duncan's test of the investment rate value between different economic sectors that the agricultural, construction, and industrial sectors came in first place with an average of about $0.057,0.104$ and 0.178 respectively. , While the petroleum sector comes in second place with an average of about 0.236 , while the electricity sector came in third and last place with an average of about 1.066 during the average study period Table (10).

Table 10: Results of the Duncan test for the value of the investment rate coefficient among the most important different economic sectors during the period (2005-2018)

\begin{tabular}{llcc}
\hline Sector & First & The second & The third \\
\hline Agriculture & 0.057 & & \\
Construction & 0.104 & 0.104 & \\
Industry & 0.178 & 0.178 & \\
Petroleum & & 0.236 & 1.066 \\
Electricity & & & 1.000 \\
The significant differences & 0.118 & 0.087 &
\end{tabular}

Source: It was collected and calculated from Table (3) by research.

While the results of Duncan's test of the value of the return on investment coefficient between the different economic sectors revealed that the electricity sector comes in first place with an average of about 1.107, while the industry and petroleum sector comes in second place with an average of about 7,093 and 7,421 respectively, then the construction sector. In third place, with an average of about 14.107, while the agricultural sector came in fourth and last place with an average of about 19,679 during the average study period Table (11).

Table 11: Results of the Duncan test for the value of the return on investment coefficient among the most important economic sectors

\begin{tabular}{|c|c|c|c|c|}
\hline Sector & First & The second & The third & The fourth \\
\hline Electricity & 1.107 & & & \\
\hline Industry & & 7.093 & & \\
\hline petroleum & & 7.421 & & \\
\hline Construction & & & 14.107 & \\
\hline Agriculture & & & & 19.679 \\
\hline The significant differences & 1.000 & 0.896 & 1.000 & 1.000 \\
\hline
\end{tabular}

Source: It was collected and calculated from Table (4) by research. 
As indicated by the results of Duncan's test of the value of the employment factor among the different economic sectors, the agriculture, construction, construction and industry sectors came in first place with an average of about 2,414,3,493 and 14,014 respectively, while the electricity sector came in second place with an average of about 156,264, while it came The petroleum sector ranks third and last, with an average of about 331,179 during the average study period Table (12).

Table 12: Results of Duncan Test for the value of the employment factor among the most important different economic sectors during the period (2005-2018)

\begin{tabular}{|c|c|c|c|}
\hline Sector & First & The second & The third \\
\hline Agriculture & 2.414 & & \\
\hline Construction & 3.493 & & \\
\hline Industry & 14.014 & & \\
\hline Electricity & & 156.264 & \\
\hline petroleum & & & 331.179 \\
\hline The significant differences & 0.773 & 1.000 & 1.000 \\
\hline
\end{tabular}

As indicated by the results of Duncan's test of the investment value of the various economic sectors, the construction, construction and agricultural sectors come in first place with an average of about 10.524 and 15.31 billion pounds, respectively, while the agricultural sector shares with the electricity sector in second place with an average of about 15.31 and 31.388 billion. EGP respectively, while the electricity sector shares with the industrial sector with the petroleum sector in the third and last place, at an average of about $31,388,39,518,45.126$ billion pounds during the average study period Table (13).

Table 13: Results of Duncan's test of the investment value in billion pounds for different economic sectors during the period (2005-2018)

\begin{tabular}{lccc}
\hline Sector & First & the second & The third \\
\hline $\begin{array}{l}\text { Construction } \\
\text { Agriculture }\end{array}$ & 10.524 & & \\
$\begin{array}{l}\text { Electricity } \\
\text { Industry }\end{array}$ & 15.310 & 15.310 & 31.388 \\
petroleum & & 31.388 & 39.518 \\
The significant differences & 0.586 & & 45.126 \\
\hline So & & 0.070 & 0.143 \\
\hline
\end{tabular}

Source: It was collected and calculated from Table (2) by research.

We conclude from the foregoing that although the sectors of agriculture, construction, construction and industry come in first place in terms of efficiency of the rate of investment, and the sectors of agriculture, construction and construction are ranked first in terms of the value of investments directed to them, despite the fact that the agricultural sector comes in the fourth and last place of In terms of the efficiency of the return on investment, which leads to imbalances in the way investments are distributed among those economic sectors, which requires the need to reconsider the policies of distributing national investments on the various economic sectors and paying attention to increasing investments directed to the agricultural sector.

\section{Fourth: The standard estimation of the Klein model to measure the efficiency of agricultural investment in Egypt}

Klein's model consists of three behavioral equations (Behavioral Equations) and three identification equations. The first equation assumes that an increase in both the profit of the current year and the profit of the previous year and an increase in investment in the previous year leads to an increase in investment, while a decrease in the interest rate leads to an increase in investment. . Whereas the second equation assumes that an increase in both the profit of the current year, the profit of the previous year, and the wages of labor leads to an increase in consumption. While the third equation assumes that an increase in both the gross national product in the current year and the gross national product in the previous year, and the technology represented in time leads to an increase in the demand for labor. Where :

Invst: investment in year $\mathrm{t} L d t$ : labor demand in year $\mathrm{t}$ 
Invst (-1): Investment in the previous year ( $\mathrm{t}$ ) -1 Gnpt: Gross National Product (GNP) in year $\mathrm{t}$ Proft: profit in year $t$ Gnpt $(-1)$ : gross national product in the previous year $(\mathrm{t}(-1)$ Proft (-1): profit in the previous year ( $\mathrm{t}(-1)$ Tcnt: technology (time) in year $\mathrm{t}$

Rt: interest rate in year t. Govt: government spending in year $t$ Cont: consumption in year $\mathrm{t}$ Nnpt: net national product in year $\mathrm{t}$

WLt: wages of labor in year $t$ Taxt: taxes in year $t$

WLt (-1): wages of labor in the previous year $(\mathrm{t}(-1)$

Where the model consists of six (endogenous) variables which are (gross national product, net national product, national profit, national consumption, national investment, labor demand), and five external variables (exogenous) which are (government spending, taxes, interest rate, etc.) Labor wages, technology represented in time), and three definitional equations which are (gross national product, net national product, and national profit).

It was found from the results of estimating the Klein model using the two-stage least squares minimization method that the agricultural investment function is statistically significant at the probability level of 0.01 , as the modified determination coefficient indicates that about $93.5 \%$ of the changes in agricultural investment are due to the change in the current year's profit, the previous year's profit, Agricultural investment in the previous year and the interest rate, while the rest of the changes are due to other factors not included in the model. Where it was found from the agricultural investment function that an increase in the current year's profit and previous year's profit and agricultural investment in the previous year by $1 \%$, respectively, leads to an increase in agricultural investment by $1.3 \%, 0.5 \%, 0.26 \%$, while a decrease in the interest rate leads to an increase in investment by $1.3 \% . \%$ - Table (14).

The results of the Klein model estimation showed that the agricultural consumption function is statistically significant at the probability level of 0.01 , as the modified determination coefficient shows that about $96.2 \%$ of the changes in agricultural consumption are due to the change in the current year's profit, the previous year's profit and labor wages, while the rest of the changes are due to factors Others not covered by the model. As it was found from the consumption function that an increase in the current year's profit, previous year's profit and labor wages by $1 \%$, respectively, would lead to an increase in agricultural consumption by $1.53 \%, 0.64 \%, 0.48 \%$ - Table (14).

Table 14: the standard estimation of the Klein model at the agricultural level during the period (20052018)

\begin{tabular}{|c|c|}
\hline Dependent variable & Regression functions of the Klein model \\
\hline $\begin{array}{l}\text { Agricultural investment } \\
\text { (Billion pounds) }\end{array}$ & 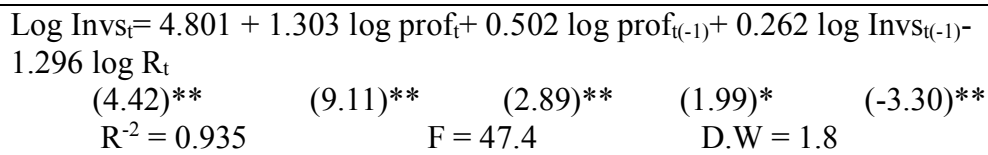 \\
\hline $\begin{array}{l}\text { Agricultural consumption } \\
\text { (Billion pounds) }\end{array}$ & 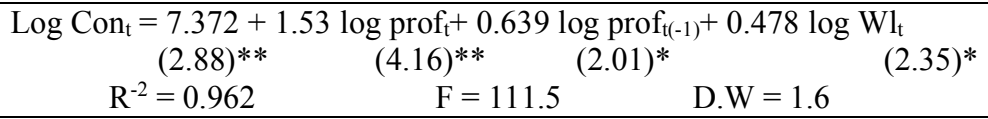 \\
\hline $\begin{array}{l}\text { Wages of agricultural } \\
\text { workers } \\
\text { (Billion pounds) }\end{array}$ & 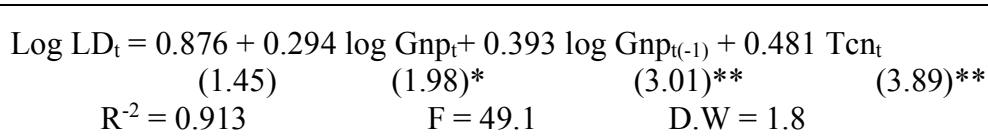 \\
\hline
\end{tabular}

**Morale when $0.01, *$ Morale when 0.05

Source: It was collected and calculated from Table (2) by research.

The results of the Klein model estimation showed that the demand function for agricultural labor wages is statistically significant at the significant level of 0.01 , as the modified determination coefficient shows that about $91.3 \%$ of the changes in the demand for agricultural labor wages are due to the change in the gross national product in the current year, the total product National and technological changes in the previous year, while the rest of the changes are due to other factors not included in the model. Where the equation of the demand for wages of agricultural labor shows that the increase in the gross national product in the current year, the gross national product in the previous year and the technological 
by $1 \%$, respectively, leads to an increase in agricultural labor wages by $0.29 \%, 0.39 \%, 0.48 \%$ - Table (14).

Fifth: the standard estimation of the Harrod and Domer model to measure the growth rate of real agricultural income:

The Hard and Domer model aims to recognize the importance of investment in achieving national income growth rates, as increasing investment leads to creating effective demand, as well as increasing the productive capacity of various goods and services. An increase in real income, as the rate of growth is determined by the ratio of saving the country's economy to the national income that turns into investment and capital coefficient, as the model assumes:

1- The existence of a relationship between the total size of the national capital stock and the national product.

2- The national economy achieves a constant percentage of savings through national income.

3 - Investment represents the amount of addition to the national capital.

As it is evident from the results of Table (15) - that the growth rate of agricultural income reached about $1.73 \%$ during the average period of study, while it was found that to achieve this rate, this required achieving an investment rate of about $6.47 \%$, as well as achieving investment productivity of about 0.43 during Study period (2005-2018).

Table 15: Evolution of the Harrod and Domer model to measure the growth rate of real agricultural income in billions of pounds during the average period (2005-2018).

\begin{tabular}{|c|c|c|c|c|c|c|c|c|}
\hline Year & $\begin{array}{l}\text { Total current } \\
\text { agricultural } \\
\text { investment }\end{array}$ & $\begin{array}{c}\text { Current } \\
\text { agricultural } \\
\text { income }\end{array}$ & $\begin{array}{c}\text { Total Real } \\
\text { Agricultural } \\
\text { Investment }\end{array}$ & $\begin{array}{c}\text { Real } \\
\text { agricultural } \\
\text { income }\end{array}$ & $\begin{array}{c}\text { Investment } \\
\text { rate (1) } \\
\%\end{array}$ & $\begin{array}{c}\text { Capital } \\
\text { factor } \\
(2)\end{array}$ & $\begin{array}{c}\text { Investment } \\
\text { productivity } \\
\text { (3) }\end{array}$ & $\begin{array}{c}\text { Income } \\
\text { growth } \\
\text { rate } \\
(4) \\
\% \\
\end{array}$ \\
\hline 2005 & 8.04 & 92.9 & 12.83 & 148.14 & 8.66 & & 0.94 & \\
\hline 2006 & 7.79 & 102.4 & 12.18 & 160.15 & 7.61 & 1.07 & 1.48 & 7.1 \\
\hline 2007 & 8.07 & 116.3 & 12.37 & 178.19 & 6.94 & 0.68 & -0.42 & 10.3 \\
\hline 2008 & 6.86 & 136.8 & 8.68 & 173.04 & 5.02 & -2.40 & 1.39 & -2.1 \\
\hline 2009 & 6.74 & 138.1 & 9.04 & 185.08 & 4.88 & 0.72 & -0.82 & 6.8 \\
\hline 2010 & 6.83 & 150.7 & 8.06 & 177.69 & 4.53 & -1.22 & 1.07 & -3.7 \\
\hline 2011 & 5.37 & 179.7 & 5.57 & 186.35 & 2.99 & 0.93 & 1.22 & 3.2 \\
\hline 2012 & 8.38 & 190.8 & 8.49 & 193.13 & 4.39 & 0.82 & 0.77 & 5.4 \\
\hline 2013 & 11.63 & 203.8 & 11.39 & 199.64 & 5.70 & 1.30 & 0.91 & 4.4 \\
\hline 2014 & 13.41 & 223.7 & 12.59 & 210.01 & 6.00 & 1.10 & 0.63 & 5.5 \\
\hline 2015 & 16.28 & 224.9 & 15.77 & 217.91 & 7.24 & 1.60 & 0.01 & 4.5 \\
\hline 2016 & 17.34 & 256.9 & 7.86 & 116.44 & 6.75 & -0.16 & -0.89 & 4.1 \\
\hline 2017 & 48.39 & 329.3 & 16.09 & 109.48 & 14.69 & -1.13 & -0.72 & -13.0 \\
\hline 2018 & 49.21 & 355.3 & 13.57 & 97.98 & 13.85 & -1.40 & 0.43 & -9.9 \\
\hline Average & 15.31 & 192.97 & 11.03 & 168.09 & 6.47 & 0.15 & 0.94 & 1.73 \\
\hline
\end{tabular}

* Current values were adjusted for real values using the general index of wholesale prices with a base year of $2016=$ 100

Source: It was compiled and calculated from Table No. (2) by research.

$$
\begin{aligned}
& \text { 1. Investment rate }=\frac{\text { Total real agricultural investment }}{\text { Real agricultural income }} \times 100 \\
& \text { 2. Capital coefficient }=\frac{\text { Total real agricultural investment }}{\text { Change in real agricultural income }}
\end{aligned}
$$$$
\text { 3. Productivity of investment }=\frac{1}{\text { Capital factor }}
$$

4. Rate of growth in income $=$ Rate of investment $x$ productivity of investment 


\section{Sixth: Standardized Estimation of the Factors Determining the Targeted Agricultural Investment Using Nirulov's Partial Adjustment Model:}

The formulation of research hypotheses for the causal relationships between the dependent variable and the independent variables is based on the identification and selection of the explanatory variables specified for agricultural investment, as the research hypotheses are limited to identifying the most important economic variables specified for agricultural investment, and the analytical model included several independent explanatory variables and a dependent variable represented in the total value of agricultural investment In billions of pounds (Y), as for the independent variables, they were:

1. Total agricultural investment in the previous year in billions of pounds $Y(-1)$

2 .The ratio of total agricultural product to GDP (X1).

3. The ratio of total agricultural foreign trade to total agricultural product (X2).

4. The exchange rate of the dollar in pounds (X3). 5- Inflation rate (x4).

6. The ratio of the general budget deficit to the gross domestic product (X5).

7. Discount price (x6). 8- Total national investment in billion pounds (X7).

The desired and target level of the total agricultural investment value was estimated using Nerlove's partial adjustment model, where the Nerolov partial adjustment model is considered a longterm dynamic model and can be formulated as follows:

Yt: the target level of the total value of agricultural investment, while the variables $\mathrm{X} 1, \mathrm{X} 2, \mathrm{X} 3, \ldots \mathrm{Xn}$ represent the actual level of the specified variables for the total value of agricultural investment.

This model is estimated as an initial step in the short run as follows:

$$
Y_{t}=a \lambda+(1-\lambda) Y_{t-1}+b_{1} \lambda X_{1}+b_{2} \lambda X_{2}+b_{3} \lambda X_{3}+e_{t}
$$

$\lambda$ : represents the adjustment factor, and its value ranges between zero and the integer one, and the value of close to zero indicates that a small part of the imbalance between the actual and the equilibrium is modified within one period of time, while the value of close to the correct one indicates that a large part of the gap Between the actual situation and its desired and targeted counterpart is covered within one period of time, and then the value of determines the speed of the adjustment or adjustment, and the average period of slowdown in the adjustment or adjustment Lag is equal to (-1). By conducting a multiple regression analysis of the explanatory variables specified for the value of agricultural investment during the period (2005-2018), the preference of the short-term double logarithmic model was found, which was converted to the long-term model using the Nerlove Adjustment Coefficient.

By estimating the multiple regression function of the factors determining the target agricultural investment during the period (2005-2018) - Table (16) - it was found that the regression coefficients are consistent with the statistical and economic logic in terms of reference, and the significance of the regression coefficients was also proven at a significant level (0.01), as it was found that The total value of agricultural investment in billion pounds $(\mathrm{Y})$ depends on the total agricultural investment in the previous year in billion pounds (-1), the ratio of total agricultural product to GDP (X1), the ratio of total agricultural foreign trade to the total agricultural product (X2), the price of The exchange of the dollar in pounds (X3), the ratio of the general budget deficit to GDP (X5), total national investment (X7) ( Eman and Walaa, 2019 , 2020).

Table 16: The standard estimate of the factors determining the targeted agricultural investment using the partial adjustment model of Nerulov in Egypt during the period (2005-2018)

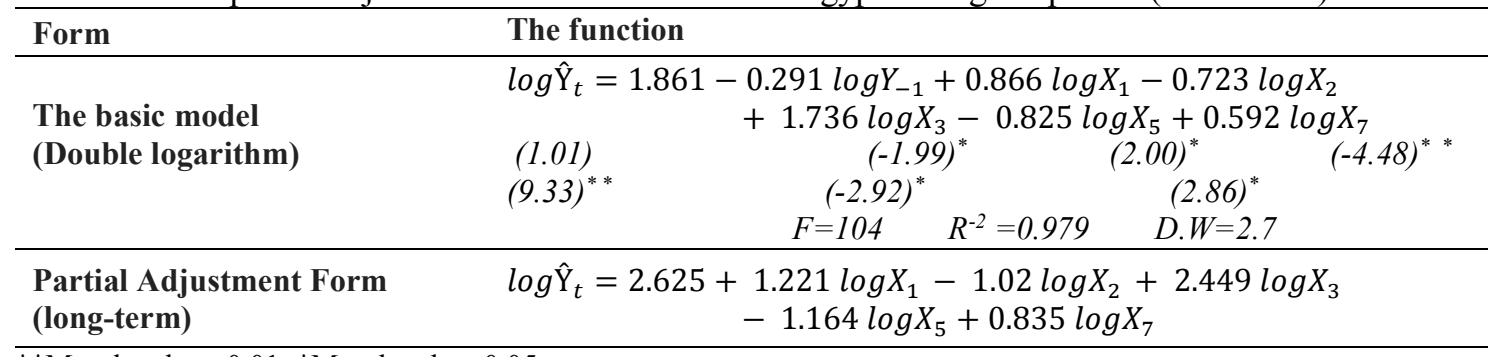

**Morale when $0.01, *$ Morale when 0.05

Source: It was collected and calculated from Table (2) by research 
Where the double logarithmic model revealed the existence of an inverse relationship between the total value of agricultural investment in billions of pounds $(\mathrm{Y})$ and each of the total agricultural investment in the previous year $\mathrm{Y}(-1)$, the ratio of total agricultural foreign trade to the total agricultural output (X2), the ratio of the general budget deficit Of the gross domestic product (X5), as it was found that an increase of $1 \%$ in each of them, respectively, leads to a decrease in the value of agricultural investment by about $0.29 \%, 0.72 \%$, and $0.83 \%$. While it was found that there is a direct relationship between the total value of agricultural investment in billions of pounds $(\mathrm{Y})$ and each of the ratio of total agricultural product to GDP (X1), the exchange rate of the dollar in pounds (X3), and total national investment (X7), where it was found that an increase of $1 \%$ In each of them, respectively, it leads to an increase in the value of agricultural investment by about $0.87 \%, 1.74 \%$ and $0.59 \%$.

It is also evident from the estimated parameters of the estimated standard model that the value of $(1-\lambda)$ in the standard short-term model amounted to about 0.71 , and then the value of the adjustment or adjustment factor () is estimated at about 0.29 , indicating that about $29 \%$ of the gap between the actual and the target situation They are adjusted within one time period, and the average slowdown required to borrow from the actual situation to the target situation is about 3.44 years. The long-term model could be expressed by the following equation:

$$
\log \hat{Y}_{t}=2.625+1.221 \log X_{1}-1.02 \log X_{2}+2.449 \log X_{3}-1.164 \log X_{5}+0.835 \log X_{7}
$$

Through the estimated long-term partial adjustment model, it becomes clear that the ratio of total agricultural product to GDP, the ratio of total agricultural foreign trade to total agricultural product, the dollar exchange rate in pounds, the ratio of the general budget deficit to GDP, total national investment are among the most important determinants of the value of Agricultural investment in the short and long term, as it was found that a $10 \%$ change in the ratio of total agricultural foreign trade to total agricultural output, and the ratio of the general budget deficit to GDP, leads to a change in the opposite direction of the targeted agricultural investment value of about $10.2 \%, 11.6 \%$ Respectively.

It was also found that a change of $10 \%$ in the ratio of the total agricultural product to the GDP, the exchange rate of the dollar in the pound, and the total national investment leads to a change in the same direction for the value of the targeted agricultural investment with a rate of about $12.2 \%, 24.5 \%$ and $8.3 \%$, respectively. By using the partial adjustment model of Nirulov, it was possible to estimate the target level for the value of agricultural investment and compare it to the actual level, as it was found from the results of Table (17) that the target level for the value of agricultural investment exceeds its actual counterpart, as the average target level for the value of agricultural investment during the average study period was about 20.04 billion pounds, While its actual counterpart was about 15.31 billion pounds, and the average percentage of the target level from its actual counterpart was about 1.71 times(Eman, 2020 a\& b, Mohamed and Eman, 2020).

Table 17: The target and actual level of the value of the Egyptian agricultural investment in billion pounds during the period (2005-2018)

\begin{tabular}{cccc}
\hline Year & $\begin{array}{c}\text { Targeted agricultural } \\
\text { investment }\end{array}$ & $\begin{array}{c}\text { Actual agricultural } \\
\text { investment }\end{array}$ & $\begin{array}{c}\text { Percentage of actual targeted } \\
\text { agricultural investment }\end{array}$ \\
\hline $\mathbf{2 0 0 5}$ & 4.95 & 8.04 & 0.61 \\
$\mathbf{2 0 0 6}$ & 7.27 & 7.79 & 0.93 \\
$\mathbf{2 0 0 7}$ & 9.59 & 8.07 & 1.19 \\
$\mathbf{2 0 0 8}$ & 11.91 & 6.86 & 1.74 \\
$\mathbf{2 0 0 9}$ & 14.23 & 6.74 & 2.11 \\
$\mathbf{2 0 1 0}$ & 16.55 & 6.83 & 2.42 \\
$\mathbf{2 0 1 1}$ & 18.88 & 5.37 & 3.51 \\
$\mathbf{2 0 1 2}$ & 21.20 & 8.38 & 2.53 \\
$\mathbf{2 0 1 3}$ & 23.52 & 11.63 & 2.02 \\
$\mathbf{2 0 1 4}$ & 25.84 & 13.41 & 1.93 \\
$\mathbf{2 0 1 5}$ & 28.16 & 16.28 & 1.73 \\
$\mathbf{2 0 1 6}$ & 30.48 & 17.34 & 1.76 \\
$\mathbf{2 0 1 7}$ & 32.81 & 48.39 & 0.68 \\
$\mathbf{2 0 1 8}$ & 35.13 & 49.21 & 0.71 \\
Average & 20.04 & 15.31 & 1.71 \\
\hline
\end{tabular}

Source: It was collected and calculated from Table (2) by research 
Through the modified model, the value of agricultural investment in Egypt can be predicted until 2025, as the estimated standard model in the short and long term has good predictive power, as the square root of the mean squares of random error (RMSE) is about 1.204 and the average absolute error (MAE) is about 0.851 . The inequality coefficient of U-Theil also approached zero, reaching about 0.026 , as it was found from the results of forecasting the value of the targeted agricultural investment until 2025 that the value of agricultural investment is expected to increase from about 49.21 billion pounds in 2018 to about 51.38 billion pounds in 2025 . With an annual average estimated at 47.9 billion pounds during the period (2022-2025) - Table (18).

Table 18: The target level for the value of agricultural investment is expected in billions of pounds until 2025

\begin{tabular}{cc}
\hline Year & The targeted value of the agricultural investment \\
\hline $\mathbf{2 0 2 2}$ & 44.41 \\
$\mathbf{2 0 2 3}$ & 46.73 \\
$\mathbf{2 0 2 4}$ & 49.06 \\
$\mathbf{2 0 2 5}$ & 51.38 \\
Average & 47.90 \\
\hline
\end{tabular}

Source: It was compiled and calculated from Table (2) by research and modified long-term standard Nirulov model.

\section{The most important findings of the study were found:}

Increase in the total domestic investment and agricultural investment at an increasing growth rate of about $9.0 \%$ and $10.1 \%$ of the average of about 279.3 and 15.31 billion pounds, respectively, during the study period.

As revealed from the results of Duncan's New Multiple Range Test, although the agriculture, construction, construction and industry sectors come in the first place in terms of the efficiency of the investment rate, the agricultural, construction and building sectors are ranked first in terms of value The investments directed to them, despite the fact that the agricultural sector ranks fourth and last in terms of the efficiency of return on investment, which leads to imbalances in the way investments are distributed to those economic sectors, which requires the need to reconsider the policies of distributing national investments to different economic sectors and interest By increasing investments directed to the agricultural sector.

Whereas, the results of the standard evaluation of the Klein model for measuring the efficiency of agricultural investment in Egypt showed that increasing the current year's profit, the previous year's profit, and the previous year's agricultural investment by $1 \%$, respectively, leads to an increase in agricultural investment by $1.3 \%, 0.5 \%, 0.26 \%$, while A decrease in the interest rate leads to an increase in investment by $1.3 \%$. While it was found that an increase in the current year's profit, previous year's profit and labor wages by $1 \%$, respectively, leads to an increase in agricultural consumption by $1.53 \%$, $0.64 \%, 0.48 \%$. However, the increase in the gross national product in the current year, the gross national product in the previous year and the technological by $1 \%$, respectively, would lead to an increase in agricultural labor wages by $0.29 \%, 0.39 \%, 0.48 \%$.

The results of the standard estimation of the Harrod and Domer model for measuring the growth rate of real agricultural income showed that the rate of growth of agricultural income amounted to about $1.73 \%$, while it was found that to achieve this rate, this required achieving an investment rate of about $6.47 \%$, as well as achieving investment productivity of about 0.43 during the study period.

While the results of the standard assessment of the most important factors determining the value of the targeted agricultural investment using Nirulov's long-term partial adjustment model were found.

During the period (2005-2018), the ratio of total agricultural product to GDP, the ratio of total agricultural foreign trade to total agricultural product, the dollar exchange rate in pounds, the ratio of the general budget deficit to GDP, total national investment are among the most important determinants of the investment value. In the short and long term, it was found that a $10 \%$ change in the ratio of total agricultural product to GDP, the ratio of total agricultural foreign trade to total agricultural product leads to a change in the opposite direction of the targeted agricultural investment value of about $10.2 \%$, $11.6 \%$.

It was also found that a $10 \%$ change in the exchange rate of the dollar in the pound, the ratio of the general budget deficit to the GDP, and total national investment leads to a change in the same direction of the targeted agricultural investment value of about $12.2 \%, 24.5 \%$ and $8.3 \%$, respectively. 
Through the modified Nirulov model, it was possible to predict the target agricultural investment value until 2025, as it is expected to increase the value of agricultural investment from about 49.21 billion pounds in 2018 to about 51.38 billion pounds in 2025, with an annual average estimated at about 47.9 billion pounds during the period (2022-2025).

\section{Recommendations:}

1. Encouraging investment in agricultural projects and reducing interest rates and taxes to attract local and foreign capital to establish agricultural projects.

2. Work to remove the obstacles and problems that hinder agricultural investment so that the agricultural sector can achieve the highest possible efficiency from the use of available resources, as it is evident that the efficiency of agricultural investment is high.

3. Work to increase the value of agricultural investments to reach the target level.

\section{References}

Ahmed Mahmoud Abdel Aziz, 2014. A Benchmark Analysis of Agricultural Investment in Egypt, Assiut Journal of Agricultural Sciences, Volume No. 45, Issue (4).

Amani Ali Mohamed, 2008. A Study of Investment Efficiency in the Egyptian Agricultural Sector, The Egyptian Journal of Agricultural Economics, Volume 18, Issue 3, September.

Dalia Hamid Al-Shuwaikh, 2016. The Strategy for the Distribution of Public Investments on the Commodity Sectors and Their Implications for the Agricultural Sector in Egypt, Assiut Journal of Agricultural Sciences, Volume No. 47, Issue (1).

Eman Abd Elghafour Ahmed and Walaa Ali Mohamed, 2020. An economic study of the marketing windows of the Egyptian potato crop for the most important foreign markets, Plant Archives Vol. 20, Supplement (2):

Eman Abd Elghafour Ahmed and Walaa Ali Mohamed, 2019. An Economic Study to Estimate the Ideal Demand for Meat in Egypt, Journal of Behavioural Economics, Finance, Entrepreneurship, Accounting and Transport, 7(1):10-16.

Eman Abd-Elghafour Ahmed, 2016. Estimation of Water Footprint and Virtual Water for Rice in Egypt, International Journal of ChemTech Research, 9(12):28 -50

Eman Abd-Elghafour Ahmed, 2020a. Standard Estimate of the impact of Exchange Rate liberalization on agricultural foreign trade of the most important global, Plant Archives, 20, Suppliment (1):1415-1426.

Eman Abd-Elghafour Ahmed, 2020b. Competitiveness of Egyptian onion exports to the most important European Union countries, Plant Archives, 20 Suppliment (1):2109-2118.

Johnston, J., Econometric Methods, 3rd, McGraw-Hill Book Company, New York, 1984.

Mamdouh Al-Badry and others, 2009. A standard model for the impact of the efficiency of national and agricultural investment in the Arab Republic of Egypt in light of the global economic crisis "The Egyptian Association for Agricultural Economics, the seventeenth conference of agricultural economists, from 14 to 15 October.

Mamdouh Elbadry and others, An Economic Study for Local and Foreign Agricultural Investment in Egypt, An International Conference on International Economics and Development, Berlin, Germany, ICIED 2019.

Mohamed Abdel-Raheem and Eman AbdElghafour, 2020. Insects and the Economics of Sugar Beet Crop, Lambert Academic Publishing, ISBN : 978-620-2-78868-7, Pp 96.

Muhammad Ali Shata, Shahinaz Eid Musa, 2010. A benchmark analysis of actual and targeted investment in the Egyptian agricultural sector, Mansoura Journal for Agricultural Sciences, Faculty of Agriculture, Mansoura University, Volume (1), Issue (12), December.

Thanaa Al-Noubi Ahmed Selim, 2008. An Analytical Study of the Factors Affecting National and Agricultural Investment in Egypt, The Egyptian Journal of Agricultural Economics, Volume Eighteenth, Number Three, September.

The Central Bank of Egypt website www.cbe.org.eg

The website of the Central Agency for Public Mobilization and Statistics www.capmas.gov.eg

The website of the Ministry of Planning, www.mop.gov.eg. 